\title{
How to develop loT products: a technology company case study
}

\author{
Diego de Castro Fettermann, Eduardo Alves Kloppel, Caroline Gobbo Sá Cavalcante, Marianne Costa Avallone, \\ Lynceo Falavigna Braghirolli \\ Departamento de Engenharia de Produção e Sistemas, Universidade Federal de Santa Catarina - UFSC \\ e-mails: d.fettermann@ufsc.br; eduardoalveskloppel@gmail.com; carolinegobbosa@gmail.com; arq.marianne.costa@gmail.com; lynceo@gmail.com
}

\begin{abstract}
The implementation of Product Development Processes (PDP) is an approach for systematizing the innovation process in companies. Given the trend of autonomous connectivity and information processing, with the controlled performance of products promoted by the Internet of Things, it has become increasingly necessary to study how companies should adapt their PDP to develop smart products. Hence, the purpose of this study is to compare a theoretical IoT product development model to a model currently in practice by a technology company. The results indicate that the company's experience has adherence to the theoretic IoT product development proposals, performing most of the activities recommended by the literature. Among the activities considered critical for IoT Product Development, the results revealed a great difficulty for the company to implement product monitoring actions. Although the literature suggests a large scope of possibilities on monitoring products performance, in this company, the implementation of product monitoring systems is still on an inception stage.
\end{abstract}

Keywords: new product development, internet of things, practices.

\section{Introduction}

Technological development has directly impacted on market demands and consumer approach, turning IoT products into a trend for most sectors of the industry (PRICE..., 2016). The Internet of Things (IoT) refers to a network of devices and machines capable of interacting with each other (LEE; LEE, 2015), and opens a new era of connectivity between objects, people and the environment (TAO et al., 2016). Its applications are aimed at both domestic use as well as commercial and business use (ATZORI; IERA; MORABITO, 2010; HEMILÄ, 2015; FETTERMANN; ECHEVESTE; TORTORELLA, 2017, FETTERMANN et al., 2018; CALEGARI; FETTERMANN, 2018; ALMEIDA; AVALONE; FETTERMANN, 2019), and its strong potential of lifestyle transformation is a consensus among several authors (JU; KIM; AHN, 2016). The Internet of Things configures a scenario characterized by devices connected through information technologies (MIHOVSKA; SARKAR, 2018) for communicating, storing and interacting with the environment through a network (PRICE..., 2017). Some companies such as Apple, Google (MANI; CHOUK, 2017), FedEx and General Electric (LEE; LEE, 2015) are already developing and commercializing smart products.

IoT products' ability of collecting and processing data offers the possibility of monitoring product performance, developing alternatives for customer segmentation and product and services customization (PORTER; HEPPELMANN, 2015). The output of the application of such technologies might guide companies toward the conception of more innovative products and effective development processes (PORTER; HEPPELMANN, 2015).

Estimations show that by 2020, billions of products will have incorporated IoT technologies into their operation, enabling some interactivity in their functionalities (LEE; LEE, 2015). This scenario pushes companies into an agile adaptation of their PDP for the development of smart products. Previous research indicates that developing an IoT product requires a set of activities that differ from those used to develop an ordinary product (KIRITSIS, 2011; NAMBISAN, 2013; DAWID et al., 2017; HOLLER et al., 2017), but these activities are not yet organized into a systematic process for developing smart products (HOLLER; UEBERNICKEL; BRENNER, 2016).

Therefore, this study is based on the introduction of a product development model in a technology company and the comparative analysis between its actual practices and the theoretic proposal of Cavalcante and Fettermann's (2019) for an IoT NPD model, adapted from Rozenfeld et al. (2006). The study investigates divergences between theory and practice and also presents recommendations for improvements in the product development processes. 


\section{2. $10 \mathrm{~T}$ product development process}

Despite the need for adapting from traditional NPD to IoT product development (KIRITSIS, 2011; NAMBISAN, 2013; DAWID et al., 2017; HOLLER et al., 2017;ECHEVESTE; SIGNIFICANT; FETTERMANN, 2017), it has not been yet possible to identify in the literature a report that compiles, combines or structures those adaptations, neither an NPD model focused on smart products. With that purpose, the study developed by Cavalcante and Fettermann (2019) presents a compilation of the adaptations and emphases given to each activity proposed by Rozenfeld et al. (2006), resulting in a total of 1627 recommendations for IoT product development. These recommendations describe the IoT product development essential activities, with the tools, resources and structures related to their practice. Based on the model proposed by Rozenfeld et al. (2006), these recommendations were organized into phases and macro phases. Alongside the activities already provided in the model, the literature recommended the inclusion of new activities, adding four activities to the original model. Furthermore, Cavalcante and Fettermann's (2019) study presents the contribution percentage of the recommended activities over each of those phases proposed by Rozenfeld et al. (2006). Figure 1 summarizes the value of these activities' contribution to each IoT NPD phase.

\section{Research method}

\subsection{Company profile}

The company under scrutiny has been active in the technology sector for nearly 50 years, with products in the security, network, communication, and energy fields. The company's products in the national market are available in thousands of points of sale and are distributed

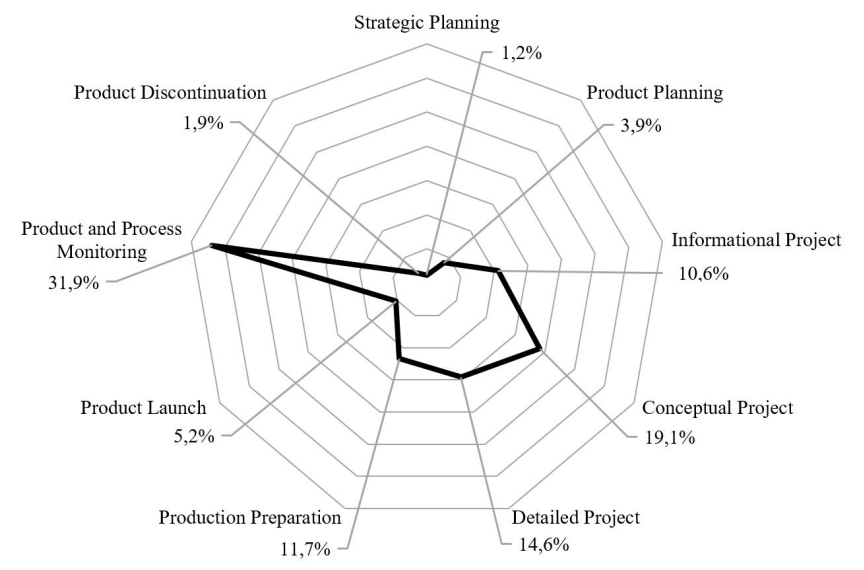

Figure 1. Contribution percentage of IoT NPD activities per phase. Source: adapted from Cavalcante and Fettermann (2019). to more than 20 different countries. Their portfolio offers products and integrated solutions that supply residential and corporative consumer markets, as well as "smart city" projects. Its manufacturing activities are developed in several industrial parks nationwide, but also include production in Asian countries. Currently, it counts with a workforce of more than 3 thousand direct employees and a research and development laboratory, with annual sales over BRL 1 billion, according to corporate data from 2015.

\subsection{Comparison between the actual PDP model and the literature suggestion}

After verifying the adherence level of the activities proposed in the theoretical IoT PDP model and those practiced by the company, the activities considered most critical for the development of IoT products were also analyzed. The survey developed by Cavalcante and Fettermann (2019) has identified the number of recommendations for each activity in IoT product development. Based on that information, two activities were considered as critical, summing 643 recommendations and representing nearly $40 \%$ of the total of recommendations identified in the literature (Table 1) (CAVALCANTE; FETTERMANN, 2019).

\section{Results}

\subsection{Company adherence level to the loT NPD model}

To identify the adherence of the company's activities to the Rozenfeld et al. (2006) model adaptation for IoT products (CAVALCANTE, 2019; CAVALCANTE; FETTERMANN, 2019), a questionnaire was designed, considering the activities associated to each phase of product development and attributing a scale to identify the level of achievement of each recommended practice in the company. The scale varies from ' 0 ', indicating a total absence of activity, to ' 3 ', indicating complete realization of activity (Figure 2). A survey through questionnaire-based interviews with NPD project managers was followed by a documental analysis of the company development process.

Among the product development stages proposed by Rozenfeld et al. (2006) and adapted by Cavalcante and Fettermann (2019), the stages with least adherence in the company's PDP were product and process monitoring, product launch and strategic planning. The discontinuity between product development and strategic planning observed in this company is common to other companies (ECHEVESTE et al., 2017). However, the product launch and product and process monitoring stages indicate a particular posture of the company's distance to the market and its final consumers. Though this result was predictable, considering the company's approach of disseminating its products through third parties, the possibility of integrating 
Table 1. Critical activities in IoT PDP.

\begin{tabular}{|c|l|c|c|}
\hline \multicolumn{1}{|c|}{ IoT PDP activity } & Recommendations & $\%$ \\
\hline a) & Monitoring product performance (technical, economic, production and services) & 493 & 30.3 \\
\hline b) & Defining product architecture & 150 & 9.2 \\
\hline c) & Planning manufacturing and assembly processes & 87 & 5.3 \\
\hline d) & Planning a macro manufacturing process /Defining a macro process plan & 85 & 5.2 \\
\hline e) & Developing production process & 80 & 4.9 \\
\hline f) & Detailing product lifecycle and customer targeting & 69 & 4.2 \\
\hline g) & Planning manufacturing resources & 62 & 3.8 \\
\hline & Others & 601 & 36.9 \\
\hline & Total & 1627 & \\
\hline
\end{tabular}

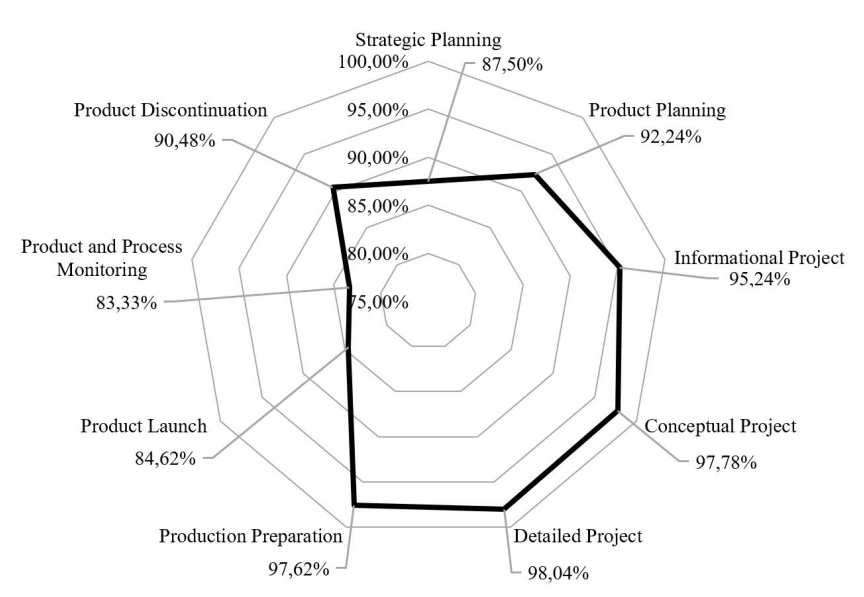

Figure 2. Company's adherence level to IoT PDP model. Source: adapted from Cavalcante and Fettermann (2019).

IoT technologies to its products could help the company to change this scenario, promoting a more active and closer relationship with the customer.

\subsection{Critical activities for loT product development}

\subsubsection{Monitoring product performance (technical, economic, production and services)}

This activity should be carried out during the product and process monitoring phase. The activity is performed according to what was planned and decided during the macro phase of development, based on information from sources such as market monitoring, distribution, production, customer care and technical support (ROZENFELD et al., 2006). Among these sources, it is noteworthy the role of the market monitoring process, often responsible for most of the information used as an input for carrying out this activity (ROZENFELD et al., 2006).

The recommendations of Rozenfeld et al. (2006) and Cavalcante and Fettermann (2019) PDP models for this activity are focused on the analysis of product information. For Rozenfeld et al. (2006), the increasing availability of IT resources allows the collection of internal and external business data with more efficient monitoring. Other literature on IoT product development mainly suggests monitoring the performance of data collection, transmission and analysis (YAN; HUANG, 2008; SUN et al., 2011; MEHRSAI et al., 2014; DAWID et al., 2017). Further studies point out the need of tracking the use of the product, software and services (KIRITSIS; KOUKIAS; NADOVEZA, 2014; CHEN, 2015; HEHENBERGER et al., 2016; WIELKI, 2017). Monitoring allows tracking historical and operational features, as well as evaluating the product's usability (PORTER; HEPPELMANN, 2014). In a more sophisticated setting, data mining makes it possible to add value to the customer through product improvements and optimization, (LYU; CHU; XUE, 2017), customer segmentation, customization of products and services (PORTER; HEPPELMANN, 2015; YU; YANG, 2016), and after-sales service packages (PORTER; HEPPELMANN, 2014; CAVALCANTE; FETTERMANN, 2019).

The company has just joined the market for IoT products and, according to the literature (YAN; HUANG, 2008; SUN et al., 2011; MEHRSAI et al., 2014; DAWID et al., 2017), there are no guidelines or practical history about monitoring the performance of data collection, transmission and analysis. The products currently included in the company's portfolio use applications and have an internet connection, with the possibility of monitoring data traffic by the use of software developed by third parties. However, the company neither manages this data nor has any access or any control over the product monitoring data. As a result, the absence of rights on the software embedded and the lack of access to monitoring and usage data prevent tracking the product use, as endorsed by the literature (KIRITSIS; KOUKIAS; NADOVEZA, 2014; CHEN, 2015; HEHENBERGER et al., 2016; WIELKI, 2017). Moreover, this condition prevents monitoring historic and operational features, that could add value to the customer through product improvements and optimization, customer segmentation, customization of products and services, and after-sales services, as recommended before (PORTER; HEPPELMANN, 2014; PORTER; 
HEPPELMANN, 2015; YU; YANG, 2016; LYU; CHU; XUE, 2017).

According to previous studies on IoT PDP models (MEHRSAI et al., 2014; DAWID et al., 2017), one way for a company to start collecting data and monitoring its products is through agreements with partners and suppliers of software and applications for collecting and storing data, making these available to the company. There are software suppliers that have already agreed on incorporating such services to the product, though the licensing fees for such software may vary according to the complexity, frequency of use and purpose of the data. Another approach to achieve that would be to purchase the software or develop its own. In any case, monitoring the product information and tracking its use would enable an information-based evaluation of the product's usability. This information would enable product improvements and optimization, market segmentation, and customization of the services offered. Nevertheless, data storage, processing and security infrastructure would still be a challenge for the company. There are no plans yet on how to carry on these procedures, becoming essential to develop a strategy to bring them to the company's routine.

\subsubsection{Defining product architecture}

This activity is the most recommended (150) in the macro phase of development, corresponding to $9,2 \%$ of all literature recommendations (CAVALCANTE; FETTERMANN, 2019). Its main tasks include the identification of systems, subsystems and components and the definition of the integration between the SSCs of project alternatives. During this activity, the product must be visualized as a sum of different parts related to individual solution principles which compose project alternatives, or complete solution principles. As a result, the product functions are supported by the alternative solutions formed by these systems, subsystems and components (ROZENFELD et al., 2006).

The literature on the development of IoT products suggests incorporating alongside the product hardware architecture the structures related its software and service definitions (BOUGDIRA; AHAITOUF; AKHARRAZ, 2016; HOLLER; UEBERNICKEL; BRENNER, 2016; TAKENAKA et al., 2016). The software definition recommendations refer to the architecture of applications (TAN; NG; LOW, 2017), platforms (THAMES; SCHAEFER, 2016), and communication protocols aimed at IoT devices (most significant; RAHMAN; SHAH, 2016). In turn, the guidelines for service architecture refer mainly to the use of cloud computing (QIN et al., 2017; MARILUNGO et al., 2017; REN et al., 2017; CAVALCANTE, 2019).

The company studied does not yet present plans for the development or use of an integrated platform of hardware, software and services as indicated before (THAMES;
SCHAEFER, 2016; TAN; NG; LOW, 2017). Moreover, there were no initiatives for the use cloud computing mechanisms for processing the company's products as already suggested (QIN et al., 2017; MARILUNGO et al., 2017; REN et al., 2017; CAVALCANTE, 2019).

\section{Conclusion}

The present research has addressed the theme of IoT product development through the case study of an active technology company. The motivation for this investigation arose from the perception of a need for adapting this company's current PDP model to a market context focused on the introduction of IoT products. This need turned into the primary purpose of this study: a comparative analysis between a theoretical IoT product development model to the model currently in practice by the company. The results revealed several opportunities to approach and leverage IoT product development.

The theoretical contributions of this research are toward the transformation of traditional PDP into IoT PDP - a theme frequently brought into discussion, but not in a systematized manner. In terms of practical contributions, this study proposes PDP adaptations for the investigated company, that can help to evolve their practices toward IoT product development.

Through the outcomes of this research, it could be observed a significant lack of adequation of traditional NPD models adopted by companies regarding the development of products which include IoT technologies and functionalities. This field of research has a lot to be explored, both in its theory, as well as in its practical applications.

\section{Acknowledgements}

The authors acknowledge the support of CNPq - National Council for Scientific and Technological Development (303936-2019-3) and CAPES - Coordination of Higher Education Personnel Improvement (Finance Code 001), since the work reported here is part of research projects under its sponsorship.

\section{References}

ALMEIDA, T. D.; AVALONE, M. C.; FETTERMANN, D. C. Buildings blocks for the development of an IoT business model. Journal of Strategy and Management, 2019. In press. https://doi.org/10.1108/JSMA-07-2019-0130.

ATZORI, L.; IERA, A.; MORABITO, G. The internet of things: a survey. Computer Networks, v. 54, n. 15, p. 2787-2805, 2010.

BOUGDIRA, A.; AHAITOUF, A.; AKHARRAZ, I. Towards an intelligent traceability system. In: INTERNATIONAL CONFERENCE ON INFORMATION TECHNOLOGY FOR ORGANIZATIONS DEVELOPMENT - IT4OD, 
2016, Fez, Morocco. Proceedings... USA: IEEE, 2016. p. 1-7.

CALEGARI, L. P.; FETTERMANN, D. C. Mass customization in food production: a perception about the theme and future directions. Product: Management \& Development, v. 16, n. 1, p. 23-36, 2018.

CAVAlCANTE, C. G. S. Adaptação do processo de desenvolvimento de produtos no contexto da internet das coisas. 2019. 153p. Dissertação (Mestrado em Engenharia de Produção)-Universidade Federal de Santa Catarina, Florianópolis, 2019.

Cavalcante, C. G. S.; Fettermann, D. C. Recommendations for Product Development of Intelligent Products. IEEE Latin America Transactions, v. 17, n. 10, p. 1645-1652, 2019.

CHEN, R. Y. Autonomous tracing system for backward design in food supply chain. Food Control, v. 51, p. 70-84, 2015.

DAWID, H. et al. Management science in the era of smart consumer products: challenges and research perspectives. Central European Journal of Operations Research, v. 25, n. 1, p. 203-230, 2017.

ECHEVESTE, M. E. S.; SIGNIFICANT, H.; FETTERMANN, D. C. Customizing practices based on the frequency of problems in new product development process. Concurrent Engineering, v. 25, n. 3, p. 245-261, 2017.

FETTERMANN, D. C. et al. How does Industry 4.0 contribute to operations management? Journal of Industrial and Production Engineering, v. 35, n. 4, p. 255-268, 2018.

FETTERMANN, D. C.; ECHEVESTE, M. E. S.; TORTORELLA, G. L. The benchmarking of the use of toolkit for mass customization in the automobile industry. Benchmarking, v. 24, n. 6, p. 1767-1783, 2017.

HEHENBERGER, P. et al. Design, modelling, simulation and integration of cyber physical systems: methods and applications. Computers in Industry, v. 82, p. 273-289, 2016.

HEMILÄ, J. Service innovations based on internet of things in industrial context. In: INNOVATION SYMPOSIUM, THE INTERNATIONAL SOCIETY FOR PROFESSIONAL INNOVATION MANAGEMENT - ISPIM, 2015, Cidade. Proceedings... Brisbane, Australia. Publisher: International Society for Professional Innovation Management ISPIM , 2015. p. 1.

HOLLER, M.; UEBERNICKEL, F.; BRENNER, W. Understanding the business value of intelligent products for product development in manufacturing industries. In: INTERNATIONAL CONFERENCE ON INFORMATION MANAGEMENT AND ENGINEERING, 8., 2016, Istanbul. Proceedings... Istanbul: ACM, 2016. p. 18-24.
HOLLER, M. et al. Digital product innovation in manufacturing industries-towards a taxonomy for feedback-driven product development scenarios. In: HAWAII INTERNATIONAL CONFERENCE ON SYSTEM SCIENCES, 50., 2017, Hilton Waikoloa Village, Hawaii. Proceedings... USA: Association for Information Systems, 2017. p. 4726-4735. Available from: <https://aisel.aisnet.org/hicss-50/os/ digital_innovation/4/>. Access in: 20 May 2019.

JU, J.; KIM, M.-S.; AHN, J.-H. Prototyping business models for IoT service. Procedia Computer Science, v. 91, p. 882-890, 2016.

KIRITSIS, D. Closed-loop PLM for intelligent products in the era of the Internet of things. Computer Aided Design, v. 43, n. 5, p. 479-501, 2011.

KIRITSIS, D.; KOUKIAS, A.; NADOVEZA, D. ICT supported lifecycle thinking and information integration for sustainable manufacturing. International Journal of Sustainable Manufacturing, v. 3, n. 3, p. 229-249, 2014.

LEE, I.; LEE, K. The Internet of Things (IoT): applications, investments, and challenges for enterprises. Business Horizons, v. 58, n. 4, p. 431-440, 2015.

LYU, G.; CHU, X.; XUE, D. Product modeling from knowledge, distributed computing and lifecycle perspectives: a literature review. Computers in Industry, v. 84, p. 1-13, 2017.

MANI, Z.; CHOUK, I. Drivers of consumers' resistance to smart products. Journal of Marketing Management, v. 33, n. 1-2, p. 76-97, 2017.

MARILUNGO, E. et al. From PSS to CPS design: a real industrial use case toward Industry 4.0. Procedia CIRP, v. 64, p. 357-362, 2017.

MEHRSAI, A. et al. Make-to-XGrade for the design and manufacturing of flexible, adaptive, and reactive products. Procedia CIRP, v. 21, p. 199-205, 2014.

MIHOVSKA, A.; SARKAR, M. Smart connectivity for internet of things (IoT) applications. In: YAGER, R. R.; PASCUAL ESPADA, J. (Ed.). New advances in the internet of things. Studies in computational intelligence. Cham: Springer, 2018. v. 715.

NAMBISAN, S. Information technology and product/service innovation: a brief assessment and some suggestions for future research. Journal of the Association for Information Systems, v. 14, n. 4, p. 215, 2013.

PORTER, M. E.; HEPPELMANN, J. E. How smart, connected products are transforming competition. Harvard Business Review, v. 92, n. 11, p. 64-88, 2014.

PORTER, M. E.; HEPPELMANN, J. E. How smart, connected products are transforming companies. Harvard Business Review, v. 93, n. 10, p. 97-114, 2015. 
PRICE WATER COOPERS - PwC. Industry 4.0: building the digital enterprise. 2016. Available from: $<$ https://www. pwc.com/gx/en/industries/industries-4.0/landing-page/ industry-4.0-building-your-digital- enterprise-april-2016. pdf $>$. Access in: 20 May 2019.

PRICE WATER COOPERS - PwC. The internet of things. 2017. Available from: <http://usblogs.pwc.com/emergingtechnology/wp-content/uploads/2017/12/Internet-ofThings-Guide.pdf $>$. Access in: 15 May 2019.

QIN, J.; LIU, Y.; GROSVENOR, R. A framework of energy consumption modelling for additive manufacturing using internet of things. Procedia CIRP, v. 63, p. 307-312, 2017.

RAHMAN, R. A.; SHAH, B. Security analysis of IoT protocols: a focus in CoAP. In: MEC INTERNATIONAL CONFERENCE ON BIG DATA AND SMART CITY ICBDSC, 3., 2016, Muscat, Oman. Proceedings... USA: IEEE, 2016. p. 1-7.

REN, L. et al. Multi-bearing remaining useful life collaborative prediction: A deep learning approach. Journal of Manufacturing Systems, v. 43, p. 248-256, 2017.

ROZENFELD, H. et al. Gestão de desenvolvimento de produtos: uma referência para melhoria do processo. São Paulo: Saraiva, 2006.

SUN, Z. W. et al. Research on manufacturing supply chain information platform architecture based on internet of things. Advanced Materials Research, p. 2344-2347, 2011.

TAKENAKA, T. et al. Enhancing products and services using smart appliance networks. CIRP Annals-Manufacturing Technology, v. 65, n. 1, p. 397-400, 2016.
TAN, Y. S.; NG, Y. T.; LOW, J. S. C. Internet-of-things enabled real- time monitoring of energy efficiency on manufacturing shop floors. Procedia CIRP, v. 61, p. 376-381, 2017.

TAO, F. et al. Internet of things in product life-cycle energy management. Journal of Industrial Information Integration, v. 1, p. 26-39, 2016.

THAMES, L.; SCHAEFER, D. Software-defined cloud manufacturing for industry 4.0. Procedia CIRP, v. 52, p. 12-17, 2016.

WIELKI, J. The impact of the internet of things concept development on changes in the operations of modern enterprises. Polish Journal of Management Studies, v. $15,2017$.

YAN, B.; HUANG, G. Application of RFID and internet of things in monitoring and anti-counterfeiting for products. In: INTERNATIONAL SEMINAR ON BUSINESS AND INFORMATION MANAGEMENT - ISBIM'08, 2008. Wuhan, China. USA: IEEE, 2008. p. 392-395.

YU, S.; YANG, D. The role of big data analysis in new product development. In: INTERNATIONAL CONFERENCE ON NETWORK AND INFORMATION SYSTEMS FOR COMPUTERS - ICNISC, 2016, Cidade. Proceedings... USA: IEEE, 2016. p. 279-283.

ZIORA, A. C. L. The role of big data solutions in the management of organizations. Review of selected practical examples. Procedia Computer Science, v. 65, p. 10061012, 2015. https://doi.org/10.1016/j.procs.2015.09.059. 